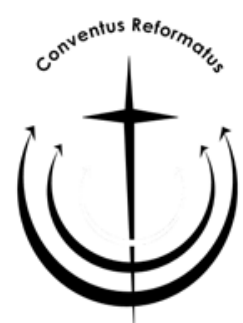

\title{
Calvin on church and government
}

\author{
W.A. Dreyer \\ Department of Church History \\ University of Pretoria \\ PRETORIA \\ E-mail: wim.dreyer@up.ac.za
}

\section{Abstract \\ Calvin on church and government}

This article examines Calvin's understanding of civil government as well as the relationship between church and government against the background of radical political change during the sixteenth century. It becomes clear that Calvin had an organic understanding of church, government and people. These three entities are interwoven and interact on the basis of the covenant and civil contract. Calvin's approach, however, is not limited to the covenant, but has a surprising richness and diversity. He integrated theological, juristic and philosophical concepts in his understanding of the state. It is further shown that Calvin's high regard for civil government, entrenched the corpus christianum, even though he clearly distinguished between ecclesiastical and civil governance. It is also shown that Calvin had a fundamental influence on many of the political concepts which are generally accepted within modern democracies.

\section{Opsomming}

\section{Kerk en owerheid in die denke van Calvyn}

Hierdie artikel gee 'n kort uiteensetting van Calvyn se denke oor die kerk en owerhede, sowel as die verhouding tussen kerk en owerheid teen die agtergrond van die radikale politieke transformasie gedurende die sestiende eeu. Dit is duidelik dat Calvyn 'n organiese staatsbeskouing ontwikkel het. Die kerk, owerheid en volk het as een organisme gefunksioneer. Die drie entiteite was verweef en het in voortdurende interaksie met mekaar geleef op grondslag van die verbond en kontraktuele verbintenis. Sy verbondsmatige denke is verder aangevul met ander teologiese, juridiese en filosofiese insigte. Dit vertoon dus 'n verrassende diversiteit. Calvyn se positiewe waardering vir die 
owerheid het daartoe bygedra om die corpus christianum te bestendig, alhoewel hy baie duidelik onderskei het tussen die verantwoordelikhede van die kerklike en siviele regering. Daar word ook aangetoon dat Calvyn 'n fundamentele invloed op die vorming van die moderne, demokratiese regstaat gehad het.

\section{Introduction}

The sixteenth-century Reformation was as much a political as an ecclesiastical revolution.

In many areas, reformed churches were persecuted by governments. This meant that the relationship between the church and the government had been problematic from the very start of the Reformation. Based on the principle of cuius regio eius religio, governments regarded any opposition to the Roman Catholic Church not only as heresy, but as political insubordination. Against this background, tension between reformed churches and governments could not be avoided (Torrance, 1990:8).

Examples of such conflict are Luther's trial at the diet of Worms (Germany); the Huguenots' resistance to the ius majestatis which exalted the king above the law (France); the fierce battles of the Covenanters against the Catholic authorities (Scotland); the efforts of the Puritan movement (England) as well as the Eighty Year War between the Netherlands and Spain (Laski, 1972:19).

Two incidents acerbated the situation. The first was the bloody extermination of Huguenots by the French king during 1572, and the second was the execution of Mary, Queen of Scots in 1587. These incidents sparked a debate on the rights of the people to resist a legal government, the rights of kings and governments and the rights of the people over and against the absolute power of the king. The Reformation took place against the background of radical sociopolitical changes which changed the face of Europe forever (Bakhuizen van den Brink, 1980:12). The Holy Roman Empire was divided by internal conflict and crumbled under the pressure of rising nationalism. The result was the emergence of national states, the end of the feudal system, the development of early capitalism as well as greater economic and political freedom (Harrison, 1975:297).

This article examines Calvin's understanding of church and civil government, as well as the relationship between the two entities. It is also shown that Calvin had a fundamental influence on many of the 
political concepts which are generally accepted within modern democracies.

\section{Early reformers}

How did reformed theologians respond to the challenges of a changing society? How did they contribute to change?

In his response, Luther formulated his concept of two regiments. He stated that God is working in a twofold manner in creation: firstly, God works in and through the church; and secondly, God works directly in the world through people and governments (Kooiman, 1957:1106). This formulation must be understood within the context of his theocentric thinking and theology of creation.

In Switzerland, Huldrych Zwingli started restructuring church and society. His ideas were implemented by the government of Zürich which influenced the city states in the rest of Switzerland. The theology of Zwingli was fundamentally influenced by the medieval corpus christianum. This meant that the respublica christiana and ecclesia were synonymous. The corpus christianum was best described in the works of Thomas Aquinas (Villa-Vincencio, 1986:24). He wrote in chapter fourteen of his De Regno that the best governments are those who submit themselves to the governance of the eternal King, Jesus Christ. The government must rule in accordance to the will of God. Every member of society should be baptised. As such, there is no distinction between the church and the people.

Although the early reformed theologians (and Calvin) differed fundamentally in their understanding of the church, they maintained the corpus christianum during the reformation of church and state (Pont, 1986:30). This resulted in the establishment of national and state churches, which in some instances still exist today, pervading 21st century ecclesiology in many subtle ways.

\section{Geneva}

In the history of political thought in the sixteenth century, there was no agent of more importance than John Calvin (Allen, 1961:49). This has much to do with the fact that he studied law at Orleans (1528) and Bourges under Alciati (1529). This culminated in his commentary on Seneca's De Clementia (1532).

The changes in society, in terms of political and economic restructuring, led to the emergence of small city states like Geneva. These 
cities were strong economic centres with citizens who became more educated. Early forms of democratic governance emerged. The feudal system became obsolete and the economies were restructured according to early forms of free trade and capitalism.

In 1536 when Calvin arrived in Geneva, the city already functioned as an independent, republican and federal city state. The city got rid of the Duke and the Bishop. The Supreme Council of Geneva regarded church and state as identical. As a result the political leadership took most of the decisions on behalf of the church. After listening to the presentations of the ministers, the city council would deliberate and conclude all church matters. This situation was unacceptable to Calvin and led to his banishment from Geneva in 1538. After he left Geneva, the situation deteriorated to such an extent that the Genevan authorities asked him to return. He arrived in 1541, and immediately started implementing ordinances which placed church governance in the hands of the church council (Pont, 1986:31). It was especially the ecclesiastical discipline which he believed to be the responsibility of the church council.

Calvin, like Zwingli, viewed the citizens of Geneva as God's people, brought together by the covenant and sacraments. However, he did not think of the church and the Genevan nation as completely identical, because among the baptised people there are always sinners and unbelievers. The church and the people of God are a corpus permixtum, with true believers and hypocrites intermingled. The difference between Calvin and Zwingli in terms of how far the church and people could be identical was the result of Calvin's ecclesiology as well as his understanding of the covenant. Calvin regarded the church as an instrument of God's grace. The church as an institution does not control salvation or grace, but can only proclaim the gospel and preach that salvation is possible through grace in Jesus Christ. Calvin understood the church from the perspective of Christology.

Calvin also understood that people need an external medium to lead people to faith in Jesus Christ and to cultivate and maintain their faith. This external medium is the church. Through the church, the preaching of the Word, the sacraments and pastoral care of the ministers and elders, members of the church can be nourished and strengthened in their faith. God chose to use the church in his work. People should respect the church as an instrument in God's hand and should become members of the true church (Inst. 4.1.5). 


\section{Covenant}

According to Calvin's understanding, the church is the result of God's covenant with people. All the faithful must be members of the true church. Baptism is a sign of the unity between believers and Christ as well as the covenant (Inst. 4.15.1). In his discussion of infant baptism, it becomes clear that he understood the church within the framework of the covenant (Inst. 4.16). However, Calvin understood the covenant differently than Zwingli and Bullinger. He understood it as a covenant of grace, and not as a bilateral relationship between God and people. Pont (1986:32) explains it as follows:

Calvyn grens voortdurend teen die Zürichse opvatting af waar die verbond sonder meer die basis van die pneumatokratiese owerheid en burgerlike gemenebes is en die staat as ' $n$ heilige Godstaat verstaan word. Juis deur duidelik tussen die burgerlike en kerklike regering te onderskei en aan te toon dat hulle op verskillende vlakke staan, kan Calvyn hierdie misvatting in sy teokratiese visie van die respublica christiana vermy. Vir 'n groot deel word dit bepaal deur die feit dat Calvyn die genadeverbond nie as 'n bilaterale verhouding tussen God en mens, soos by die Zürichse teoloë, verstaan nie. Calvyn sien die genadeverbond primêr as 'n testament waar God, op grond van die soenverdienste van Jesus Christus, sy genadegawes aan die mens gee.

This also has major implications for his understanding of the relationship between church, government and the people. His understanding of the covenant eventually played a big role in the development of political theory in reformed countries (Torrance, 1990:1). It filled the political vacuum which appeared after the disintegration of the medieval feudal system. It also opposed the notion of absolute power and godly rule (ius majestatis) vested in kings.

As a result, several covenants were formed in reformed countries. In Scotland, 24 such covenants were formed between 1556 and 1599 by so called Covenanters. These were based on the covenants of the Old Testament. It became the structure within which the relationship between church, government and people took form (Barnett, 1928:23-25; Kerr, s.a.:23, 39-51). Some roots of modern democracies are to be found in this approach. The fundamental political problem of the sixteenth century was the protection of established rights of kings, as well as establishing protection of the people against the absolute powers of the monarchy. The rights and responsibilities of the people as well as governments were described and formulated in terms of the covenant (Torrance, 1990:9). 
In the agreements (covenants) the rights and position of the church, people and authorities were clearly defined. The covenants were formally presented to all role players, and enacted with solemn oaths in the presence of the Almighty God. In accordance with the Old Testament model, it was always understood as a covenant between God, church, people and king. As a result, government had the responsibility to protect the church and promote the Christian faith and true reformed teaching.

Torrance (1990:11) comes to the conclusion:

It is abundantly clear that the concept of a foedus naturale was not only the coordinating principle of federal theology, but also fundamental for the political thinking of our Puritan, covenanting forefathers. Here was a conceptual matrix (with its notions of natural law, contract, ius naturale, ius civile, ius gentium, sovereignty, etc. so familiar in Western Europe), within which Calvin's theology was readily reinterpreted as federal theology and went to the grassroots of nations and churches struggling for justice and liberty, seeking always biblical justification and precedent for their theology and practice. How do we understand the relation, not only between divine sovereignty and human will, but also between the will of the human sovereign and the will of his people under God? To both there are given the same answer, by natural law and covenant.

Caspar Olevianus, in his De substantia foederis gratuiti inter Deum et electos of 1558, made the notion popular that the covenant is the central core of Calvin's whole theology. For centuries, the foedus gratiae and the foedus naturale served as the conceptual matrix within which Calvin's theology was interpreted - also in terms of his understanding of government. In the current debate, this is not the case. As more information became available, it is clear that there are more to Calvin's understanding of the state than the concept of covenant (Torrance, 1990:2). In fact, we find a rich diversity which still influences our understanding of democracy and the mutual responsibilities of church and government.

In the following paragraphs some of these concepts are discussed.

\section{Natural law}

The influence of the lex naturae and ius naturae on Calvin (Inst. 4.20.16; Jacobs, 1971:23) is apparent when he speaks of the law of God and the law of nature (Bohatec, 1934:3-93). He argues that humans have a natural ability to understand moral and legal matters. 
Natural law is also not contrary to the law of God. The arguments which Plato, Seneca and Cicero put forward are compatible with Scripture. Clearly, his humanist training and his knowledge of Greek and Roman thoughts on the ordo naturae which exists among all peoples played a significant role in this formulation. Moral law, natural law and the law of our conscience is one and the same. This is all based on the law of God which God had given in the heart of all people.

In natural law, the relationship between the people and government is understood as a contract (Murray, 1962:22). Practically it meant that a king (or emperor) could govern several countries and peoples. For instance, the king of Spain also governed the Netherlands and parts of Germany. These countries were also divided into smaller states governed by lower aristocracy. Each political unit was contractually bound to the king. Contracts consisted of generally accepted conditions, which clearly stipulated the privileges and responsibilities of the king, lower governors and the people. This implied that the people had to subject themselves to the king, in as far he would govern in terms of the written contract. If a king's governance would jeopardise the rights and privileges of the people, it constitutes a contractual (constitutional?) crisis. The people could then, under leadership of the lower kings, resist the king or emperor.

What is quite clear is the fact that these contracts created a juridical environment within which the people, government and church could function (Bohatec, 1934:135-206). Calvin did not regard the concepts of contract and covenant as contradictory. The contract between church, government and people were interpreted in terms of the covenant. Calvin also regarded the law of God as supreme. As such, all governments must subject themselves to the law of God. This implies that no government may be exalted above the law, but must subject themselves to the law of God, natural law as well as the established contracts. In this way, Calvin's political theory greatly influenced the later development of constitutions, rule of law, democracy, human rights and social contract.

\section{Institutio Christiande religionis}

In his first publication on the De Clementia of Seneca, Calvin defines the state in terms of the Roman jurist and philosopher Cicero's understanding of the civitas. In line with Seneca and Cicero, Calvin defined the civitas as a community of people which becomes, within the framework of a legal system, an organic and living organism. In his later writings Calvin kept to this fundamental concept, even 
though he would use terms like respublica and politia. Calvin found in Plato's thoughts the metaphor of the state as a living body. Plato describes the state in terms of the human body - the mind, body and soul are organically woven into one living organism. The mind (government), the body (people) and the soul/heart are woven by God into one organically living unit (Haitjema, 1957:1140).

Calvin discussed the relationship between church and government in his Institutio christianae religionis (Inst. 4.20). The essence of this relationship, for Calvin, lies in the fact that government has a ius circa sacra, but not a ius in sacra. With this approach, Calvin maintained a distinction between church and state. Calvin differed from Luther in his understanding of the two kingdoms. Luther understood the church as the spiritual dimension of the Christian state, while Calvin stood on the view that no earthly kingdom could be identified with the kingdom of God (Du Plooy, 1992:763). The church, even in its current incomplete and broken condition, may be regarded as a sign of the kingdom of God. The visible church and kingdom are not identical, as in the Roman Catholic theology.

The fundamental difference between church and civil government, according to Calvin, is governance. The church is governed by Jesus Christ, the only King. He governs by his Word and Spirit (Pont, 1981:11). Church governance is spiritual, with the explicit objective to lead people to glorify God with their lives. On the other hand, God also instituted earthly powers and governments, which have the power of the sword. The objective of this governance is to maintain law and order. Calvin was of the opinion that the "law" should be based on the Ten Commandments. Governments did not need to invent new laws, only to interpret and apply the perfect law which is to be found in Scripture. Only mad people would dispute the legal right and status of governments and kings.

Because of this, Calvin had a very negative opinion of the radical Anabaptist movements with their opposition to earthly government. In the introduction to the 1536 edition of his Institutes, he tried to convince the king that the Reformers were not Anabaptists and that the reformed churches have great respect for the king as well as for law and order. Calvin also believed that the government has the duty and calling to protect and promote public religion and worship. Government should also encourage Christians and church leaders to live in peace with one another (Inst. 4.20.2).

Benjamin Milner (1970) proposed that Calvin's respect for order should be understood within the wider framework of his under- 
standing of divine order, as reflected in creation. According to Milner, Calvin distinguished three spheres in which God created order, namely nature, human beings and society. This order is disturbed by sin. As a result, nature is dangerous and in society human beings hate each other. To recreate order, God determined that church and civil government must govern through spiritual and earthly means. Both civil and ecclesiastical authorities have the duty to establish order in society, to the glorification of God. Calvin's perception of order and chaos determined his positive acceptance of civil authority, as well as his aspirations to establish a church order (Ordonnances Ecclésiastiques) for Geneva. Church and government are the external means by which all Christian people are assisted to live in good order and glorify God (Inst. 4.20.2).

\section{Forms of government}

Calvin distinguished between three forms of government (Inst. 4.20.8a), i.e. monarchy, aristocracy and democracy. Each of these forms of governments has inherent weaknesses. Monarchy leads to tyranny, aristocracy leads to nepotism and personal enrichment and democracy leads to chaos and disorder.

As a result, Calvin did not try to give Scriptural foundation to one form of government. One form could not be regarded as better than the other. God provided us with different forms of government as to facilitate good governance in different situations and among different people. Personally, Calvin preferred an aristocracy with a strong representation by the people (mixed form of government). In the end, it does not really matter to a Christian under which form of government he/she lives, as long as that government governs in accordance with God's will, protecting the people and the true faith.

\section{Theocracy}

Calvin's theocratic vision consisted primarily of the notion that a good government needs to ensure that both tables of the Ten Commandments are respected in society (Du Plooy, 1992:763). God gives the necessary authority and earthly power to governments to punish those who break the law (Ten Commandments). This power includes capital punishment for those who would murder or blaspheme God (Inst. 4.20.10).

The basis of temporal justice is the law of God. God's governance (theocracy) becomes visible in church discipline (spiritual, internal governance) as well as the application of law and order by govern- 
ments (external civil governance). These two institutions are clearly distinguishable, but are both important for the maintenance of order and the spread of God's kingdom. Calvin's understanding of theocracy does not imply that the functions of church and government are interchangeable. The church must never take on the function of a temporal government. Government, however, needs to listen to the preaching of the gospel by the church, subject itself to God's kingdom and govern in accordance with God's will as found in Scripture.

Although Calvin's theocratic political system and ideals did not survive eighteenth-century Europe, the general Calvinistic principles continued to influence political developments. One example is rule of law, which in our own time is regarded as the basis of all good governance. Calvin's insistence that a government is not above the law, but under the law of God, defied the ius majestatis and the absolute powers of the king. It gave impetus to the conviction that no government should be above the law (Bauer, 1965:267-269).

\section{Humanity}

Calvin commenced his career as a typical French humanist (Allen, 1961:49). All through his life, he placed a high priority on humanitas (Inst. 4.20.3.). Governments should not only govern to the benefit of the church, but also to the benefit of each man and woman so that they may receive what is theirs. We also find this in his commentary on the De Clementia of Seneca, with which he intended to convince the king to govern with clemency (clementia) and humanity (humanitas) (Wendel, 1978:27).

Humanitas was an important political maxim, which Beza and other Calvinists used to argue that governments only exist to the benefit of the people, and not the other way round. They joined Augustine when he argues in his De civitate Dei (3/4) that the civitas terrena exists only if there are people. Thus the people/nation are the primary partner in the relationship and not governments. If a government would govern without taking the people into consideration, such a government would become a magnum latrocium (a band of robbers) (Mans, 1962:96).

\section{Justice}

In addition, Calvin implored all kings to govern with justice. He held the magistrates and court of law in high esteem. He argued that they had a God-given responsibility to ensure that justice is done to 
everyone that would appear before them. He even goes as far as to say that judges were the most important people in society, because they represented God in their judgements, had power over life and death and had to make God's will visible (Inst. 4.20.4 \& 6). He also warns governments who persist in injustice, that God would punish them and would bring them to a fall (Inst. 4.20.29, 30 \& 31). The people, however, may not resist an unjust government, because God Himself would bring it to a fall.

\section{Resistance}

From what was said before, it is quite clear that Calvin respected the government as an institution ordained by God. If a government exists because of God's will and ordination, it follows that rebellion and disrespect against such a government is incompatible with the law of God. The people must obey and respect their government in everything that is good and to the glory of God (Inst. 4.20.22). Even governments who persecute the people must be obeyed and respected as an institution by God, because it might be God's way to punish the people for their sin (Inst. 4.20.25).

Obedience does have a limit. If and when a king would order his subjects to do things that are clearly contrary to the gospel, such orders must be ignored. Calvin used several examples in the Old Testament to show that Israel had been punished by God because they obeyed the godless commands of kings. With reference to Daniel, who did not obey the king's orders to pray to him, Calvin concluded that obedience to government could never be a blind and irresponsible action. The calling of a Christian is to disobey the godless commands of kings, even to their own detriment (Inst. 4.20.32).

Calvin did not support people's rebellion and war against kings and governments. This becomes clear in his correspondence, where he urged people and lower authorities not to start wars, but rather to leave countries where they were persecuted. As a result, many French protestants emigrated, also to Southern Africa.

\section{Final remarks}

Calvin had a strong sense of calling, specifically to reform the sociopolitical and cultural environment of the sixteenth-century church (Haitjema, 1957:1136). From this flowed a reformed ascetic approach, which can be typified by the expression that the church is in the world, but does not belong to the world. Haitjema (1957:1137), following Bohatec, calls it an organische Askese: 
Josef Bohatec stelt in zijn grote werk Calvins Lehre von Staat und Kirche ergens (S. $701 \mathrm{ff}$.) voor, om in plaats van 'innerweltliche Askese' van 'organische Askese' te spreken. Hij komt daartoe, doordat hij de beeldspraak van het organisme (hoofd en leden, ziel en lichaam) zo fundamenteel acht voor Calvijns opvattingen over kerk en staatsrecht, sociaal en economisch leven.

Calvin was one of the people who shaped the face of modern Europe as well as so many countries colonised by European nations. This also includes South Africa. He contributed to the development of democracy, rule of law, social justice and many other issues we today tend to take for granted.

\section{List of references}

ALLEN, J.W. 1961. A history of political thought in the sixteenth century. London: Methuen.

BAKHUIZEN VAN DEN BRINK, J.N. 1980. Handboek der kerkgeschiedenis. Band 3. Leeuwarden: De Tille BV.

BARNETT, T.R. 1928. The story of the covenant. Edinburgh: Oliver \& Boyd.

BAUER, J. 1965.Gott, Recht und weltliches Regiment im Werke Calvins. Bonn: Bouvier.

BOHATEC, J. 1934. Calvin und das Recht. Graz: Böhlaus.

CALVIJN, J. 1559. Institutio Christianae religionis. Vert. door A. Sizoo, 1949. Delft: Meinema.

DU PLOOY, A, LE R. 1992. Calvyn oor die koninkryk van God en die staat. Hervormde teologiese studies, 48(3 \& 4):759-771.

HAITJEMA, T.H.L. 1957. Calvijn en de Calvinisme. (In Waterink, J., ed. Cultuurgeschiedenis van het Christendom. Amsterdam: Elsevier. p. 1132-1175.)

HARRISON, J.B. 1975. A short history of Western civilisation. 4th ed. New York: Knopf.

JACOBS, M. 1971. Die evangelische Staatslehre. Göttingen: Vandenhoeck \& Ruprecht.

KERR, J. s.a. The covenants and the covenanters. Edinburgh: Hunter.

KOOIMAN, W.J. 1957. Luther. (In Waterink, J., ed. Cultuurgeschiedenis van het Christendom. Amsterdam: Elsevier. p. 1104-1131.)

LASKI, H.J. 1972. A defence of liberty against tyrants: a translation of the Vindiciae contra tyrannos by Junius Brutus. New York: Franklin.

MANS, C.J. 1962. Die owerheid in die Nuwe Testament en by die reformatore. Hervormde teologiese studies, 18(3):90-115.

MILNER, B.C. 1970. Calvin's doctrine of the church. Leiden: Brill.

MURRAY, A.H. 1962. The political philosophy of J.A. de Mist. Cape Town: HAUM.

PONT, A.D. 1981. Die historiese agtergronde van ons kerklike reg. DI. 1. Pretoria: HAUM.

PONT, A.D. 1986. Verbond en volkskerk. Hervormde teologiese studies, 42(1):28-76.

TORRANCE, J.B. 1990. The concept of federal theology: Was Calvin a federal theologian? Paper presented at the Calvin congress, Grand Rapids. 
VILLA-VINCENCIO, C. 1986. Between Christ and Caesar: classic and contemporary texts on church and state. Cape Town: Phillip.

WENDEL, F. 1978. Calvin. Trans. by P. Mairet. 8th ed. Glascow: Collins.

\section{Key concepts:}

corpus Christianum

covenant and civil contract

democracy and rule of law

natural law

organic interaction: church, government and people

political change during the sixteenth century

relationship: church and government

\section{Kernbegrippe:}

corpus Christianum

demokrasie en die oppergesag van die wet

natuurreg

organiese interaksie: kerk, volk en owerheid

politieke transformasie in die sestiende eeu

verbond en kontrak

verhouding: kerk en owerheid 
